\title{
Lake Powell
}

Mansour Sharifzadeh, (E-mail: msharifzadeh@ @csupomona.edu), California State Polytechnic University, Pomona

\begin{abstract}
The purpose of the 'Lake Powell' case is to help students of Strategic Management learn the process of strategic management. This case can provide an opportunity for the students to learn strategy formulation and implementation along with some of the current issues such as "cooking the books". Some sections of the Lake Powell case are real life situations, but all of the numbers and most of operations information are fictitious. Four experienced and knowledgeable men started Lake Powell Company with many opportunities and strength. However the company has lost money in the last five years. Students analyze, formulate and write an implementation of a strategy to save this company. Students then try to answer the following questions. What should be the proposed plan to Richmond for the Marina in order to have an effective, efficient, and profitable operation? How would it be funded? However the instructor will look at other scenarios and ask the students to figure out the four partner's real goal.
\end{abstract}

\section{THE SETTING}

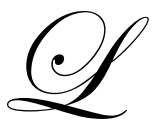

ake Powell is located between the borderline of Arizona and Utah along the Colorado River. It has a spectacular scenery view from Grand Canyon, vivid pink sunset, to a full night of stars. The possibilities of fishing, skiing, or living in the houseboat on the brilliant blue water are other options to consider. It is nearly two thousand miles of shoreline, 96 major canyons, countless coves and winding waterways. Lake Powell gives plenty of vacation options to anyone who is interested in nature.

Visitors can explore the lake's surreal formations in a powerboat, personal craft, or kayak. Powell house boats will bring the comforts of home on a lake, and make way to Tower Butt, Castle Rock, Massive LaGorce Arch and most of the famous stone bridge in the world: Rainbow Bridge National Monument.

The Rainbow Bridge National Monument is the world's largest natural stone bridge. It is sculptured by wind and water, spanning 275 feet at a height of 290 feet. The bridge is close enough to be the most photographed geological wonder in the American west. Archeologists believe Native American camped near the bridge nearly 2,000 years ago. In the National Geographic, there is a news paper article that shows visits by President Theodore Roosevelt. The western writer Zane Grey helped bring prominence and national monument status to the bridge in 1909.

Cruise Antelope Canyon has a scene with steep and red sandstone walls. From Voyage to Navajo Canyon, anyone can experience a dramatic dark desert varnish that appears like a tapestry on the towering rock walls, along with a view of Tower Butte and Navajo Arch. The next visit is the Lost Eden Canyon, streaked with a dark patina. Also Moki Canyon has a breath taking view of a long and winding gorge with immense water caves. The next place to visit is the Forgotten Canyon, pocked with lichen-covered walls and extraordinary with two cliffs dwelling tucked along a canyon shelf.

A sunset dinner cruise offers a hearty Prime Rib or vegetarian lasagna dinner aboard the Canyon King paddle wheeler to witness the lake's late-afternoon transformation as colors soften from deep reds and burnt oranges to lavender, ginger, and silver.

They offer complete houseboats vacations that depart from four full-service marinas. Pleasant accommodations are available at Wahweap, Bullfrog, Halls crossing and Hite Marinas. They also offer casual dining. 
Powerboats, personal watercraft and kayaks are available for rent. However, not all boats are available at every marina.

Ben Jenkins, the new general manager of the Wahweap Lodge on the south end of the lake at Bullfrog Marina, which offers resort-style lodging on Lake Powell's shores, had just finished his first day working. Business dropped dramatically after Labor Day, but the Marina slip rentals ran until November 21. He has decided to follow current operations for the next three weeks, and has been considering the changes that need to be implemented. Furthermore, for the Marina to survive, some short-range and long-range planning must be implemented.

Chris Dagger, the former general manager, had resigned a day before Ben Jenkins was hired. Dagger had submitted his resignation as general manger of the Marina to Phil Richmond, president of Richmond Corp. and owner of the Wahweap Lodge. Richmond and Dagger had disagreed on Dagger's compensation. Dagger had been the ninth general manager hired since the Marina had been in operation. Before being hired to manage the Marina, Dagger had nineteen years of marine experience. His experience, however, was not in Marina management, but of selling and servicing boats and motors in Lake Tahoe. He believed that the Marina had an excellent chance to turn around after some difficult times. The Marina was easily staffed because of the attractive atmosphere of the resort. His goal was to have the majority of the staff on a full time basis year-round, though the Marina is closed from November 21 until March 21. During this period of time, considerable amounts of repairs were needed on the boats. When hired, Dagger was told that he had a blank check to get the Marina shaped up. This policy was later rescinded. Chris Dagger worked six days a week and preferred not to work on Sundays. He was an effective organizer, but needed to strengthen his customer service and employee relations.

Ben Jenkins was considered a hard worker willing to take on tremendous challenges. Having had no experience in Marina management, he was about to face his biggest challenge. He joined Richmond Corp., as the accountant of the corporation after four years as a CPA in D\&J, an accounting firm. As the accountant, a huge volume of work was demanded of him, often requiring him to stay late hours at the office and to take his work to home almost every evening. At this point, Jenkins lived in a small community near the Marina. He would have to drive nearly an hour and a half one way. He mentioned that he hoped to move the offices to the Marina as soon as possible. The Marina comprised fifty percent of the corporation. Jenkins felt that if everything was at the same site handling accounting for the Marina, the Lodge and the other Richmond Corporation interests could be done more effectively.

Richmond Corp. had virtually no accounting system when Jenkins first joined the company. However, since his arrival, monthly accounting reports for the Marina had been generated.

There are also other principal investors involved in Richmond Corp. besides Phil Richmond. They are: Bill Bernard, president of one of the state's largest commercial and industrial real estate firms, and Richard Dewitt, president of Genesis Dewitt, Inc. Genesis Dewitt is the firm that designed both the Marina and the Lodge. Mike Smith, the forth partner is professor of Management at California State Polytechnic University Pomona. He has 25 years of experience in teaching and consulting in the field of management.

Phil Richmond, Chairman of the Board of East-West Baking Company, is a well-known businessman in Los Angeles. East-West Baking Company is one of the larger bakeries serving the Los Angeles metropolitan area and its surrounding counties. Phil Richmond did his undergraduate work at UCLA and completed Harvard's MBA program in 1987. He's easy-going and appears to handle problems without getting upset. He's usually in L.A., maintaining his office at the Richmond Corporation, but visits the Marina at least once a week. Phil contacts Jenkins on a daily basis. He takes pride in being a part of the daily decision-making and problem solving that goes on at the Marina. He feels that due to their weak financial position, he needs to be aware of all decisions. He believes that the current problem is due to his lack of knowledge of the Marina business and the lack of experienced general managers since the beginning of their operations six years ago. Although Jenkins has already done a lot in correcting their problems, lack of expertise in maintaining accurate cost data and cost controls have hurt them. 
Upon reviewing the structure, background, and development of the Marina, Jenkins realized the problems that faced him. Aside from being the controller of Richmond Corporation, he is now faced with new problems in his role as general manager. Running the Marina is a full time 7-day/week job, especially during the season. The two primary questions in his mind were as follows:

- What should be the proposed plan to Richmond for the Marina in order to have an effective, efficient, and profitable operation?

- $\quad$ How would it be funded?

The financial statements looked gloomy, but Jenkins had the back up data to analyze for income per square foot on most of the operations, payroll data, etc. He also possessed the knowledge from working with the past general managers and observing the operation of the Marina.

\section{LODGING AND SHOPPING}

\section{Lakeside Lodging}

Comfortable accommodations from Wahweap Lodge on the south end of the lake to Defiance House at Bullfrog Marina offer resort-style lodging on Lake Powell's shores. Wahweap has two swimming pools, a huge hot tub, gift stores, comfortable dining room, and a spacious lounge and a pizza-sandwich shop. Defiance House has a gift shop, dining room and lounge. Both of lodges offer a beautiful scenery view of the lake. The Wahweap Lodge occupies approximately 40,000 square feet on 29 acres of land. The Wahweap Lodge has 170 sleeping rooms; including singles, doubles, and suites. Meeting rooms are available for conventions and sales meeting clientele, seating for up to 400 people for dining and 650 for conferences. It is designed to attract a wide selection of the population with the low price of $\$ 84-\$ 132$ for a double room. Recreation facilities, such as indoor-outdoor swimming pools, tennis courts, sauna, whirlpool bath, are included as well as a recreation room with pool tables and other games. Additional facilities include two dining rooms and a cocktail lounge. The Wahweap Lodge is open year-round, but spring and fall are the busiest seasons.

The Mountain View, which is located five miles from the Marina, consists of 576 acres on the lake. It is a luxury condominium development designed to meet the housing needs of primary and secondary homebuyers. Its development promises a substantial boost to the Marina's business. One hundred twenty units are currently under construction with fifty of these sold and the down payments for seventy more have been received. The condominiums range from $\$ 100,000$ to $\$ 320,000$, with an average of $\$ 240,000$. The construction of 1,900 living units over a sevenyear period has been approved. Swimming pools and tennis courts are now under construction. The Mountain View is a multi-million dollar development that has a completed 18-hole golf course. Arizona Realty, Inc., and Redwood, Inc are developing it. Arizona Realty is an entirely owned subsidiary of Arizona Federal Corp., a parent firm of Arizona National Bank, the state's largest financial institution.

The Wahweap Lodge Marina occupies six acres of land. It is one of the most widespread and completes Marinas of its type in the United States. The Marina is comprised of boat docks, and a marine repair shop.

An office for boat rental is located at the end of the dock, and five gasoline pumps along with pumping facilities for waste removal from houseboats and larger cruisers.

There are a total of 460 rental slips per season (March 21 to November 20). Uncovered slips are priced from $\$ 820-\$ 3,200$ and covered slips are $\$ 1,200-\$ 4,500$. Seventy-five percent of all slips are rented due to their desirable location, under the roof. Electric service is provided to all slips, and water and trash removal are provided at no extra cost to the slips. There are 162 buoys to the left of the prime slips, renting for $\$ 600 /$ season. Rental includes shuttle boat service to and from the moored craft. The buoys require constant attention, as they sometimes break loose. Therefore, it is not considered a profitable segment. 
Lake Powell, the most beautiful lake in Arizona, with a 20,500-acre reservoir was developed by the U.S. Army Corps of Engineers in conjunction with and under the jurisdiction of the Arizona Department of Natural Resources. The surrounding public lands (accounting for some 70\% of the 190 mile shoreline) total 35,000 acres. It is a multi-purpose project designed to provide flood control, recreation, and water supply and flow augmentation, and benefits the people of Arizona.

The Reservoir is located in the southwestern quadrant of the state. A recent FORTUNE magazine survey said that it's considered a desirable site for future expansion by many of the top industrial leaders. Having recently enlarged its airport, it can accommodate any of the jet aircrafts currently in operation; and is served by most major airlines. The per capita effective buying income is $\$ 28,000$ compared to $\$ 24,000$ for the U.S. as a whole, with almost half of the households falling above the $\$ 56,000$ annual income bracket. While approximately seventy-five percent of the customers of the Marina come from the Los Angeles area.

The Wahweap Lodge complex is located on the fifty nine acres. It is leased to the corporation by the state of Arizona. In 1994, a list was distributed by the Arizona Department of Natural Resources asking for bids on a motel and Marina on the selected site. Out of the eight to ten bids submitted, only one other bidder qualified besides Richmond Corporation. Based primarily on individual economic strength and the actual content of the bid, Richmond Corporation's proposal was accepted.

The prospectus required a minimum of $\$ 40,000$ for the land rental. Richmond Corporation offered in their bid, guaranteeing $\$ 8,000$ against the first $\$ 400,000$ in Marina sales and income plus an additional six percent of all income over that amount. For the Lodge, they guaranteed $\$ 32,000$ against the first $\$ 1,600,000$ of income plus an additional four percent of all room revenue and two percent of all food and beverage sales over that amount.

Richmond was granted an initial lease of twenty eight years with two options of twenty years each. When the contract terminates, all physical property goes back to the state of Arizona and personal property including the entire structure would revert to Richmond.

Construction began in May 1991 for the initial phase of the Marina and the first one hundred slips were opened in August under an accelerated construction schedule. In November of 1994, the Wahweap Lodge had its formal opening.

\section{Small Boat Repair Shop}

Located between the docks is a small boat repair shop. It has mechanical equipment and a small lift for removing small boats from the water onto the docks for repair. This facility is idle now.

\section{Gift Shops}

Lake Powell's gift shops offer native handcrafts, jewelry, pottery, and sand paintings, and CD's relating to the area. They also offer useful items for children and adults including: fashionable t-shirts, caps, sundresses, sweatshirts, and jackets. Sundry items are also available. The stores at each marina are well stocked, which offer everything from hog dog buns to marshmallows, sun block to playing cards, or firewood to flashlights.

\section{Rainbow Room Restaurant}

The Rainbow Room offers fresh breakfast and lunch buffets and savory dinner menus. The restaurant is located in Wahweap Lodge. They are voted as one of Arizona's best restaurants because they offer expansive views of the lake's formation and shifting colors, which is adjacent to The Driftwood Lounge. 


\section{Gasoline Sales}

From seven a.m. to eight p.m., seven days a week, five gasoline pumps are operational. The pumps are located around the perimeter of the end of the center dock. The pumps for the removal of waste are also located in this area for houseboats and other large crafts. There is no charge to pump out waste and only takes an average of five minutes. The gasoline pumps are the only ones permitted access from the water on the lake.

\section{Paddle Wheeler Restaurant}

A delicious Prime Rib or vegetarian dinners are served as the sun sets, while experiencing the colors of Lake Powell as you dine aboard the Canyon King, and authentic paddle wheeler.

\section{Anasazi Restaurant}

Guests can enjoy casual to continental meals for breakfast, lunch, or dinner. While enjoying their delicious dinner they can also relax to a comfortable scenery overlooking Lake Powell at the Anasazi in Defiance House Lodge.

\section{Itza Pizza}

Guests who do not feel like leaving their room or boat can order a handmade mouth watering pizza or sandwich at Itza Pizza. Located near the main boat launch ramp at Wahweap Marina., this leisure is available during the summer.

\section{Slip Rental}

Reservations for slips must be made by December 1 of each year for the next year or the slip is subject to lease on a first come basis. Usually, all slips are rented for the year. Rental varying from $\$ 800$ to $\$ 4,000$ are available, from March 21 to November 21, depending on the size of the slip and whether it is covered or not.

\section{Buoy Rental}

195 buoys are rented at a rate of $\$ 600$ during the same March 21 to November 21 seasons. Operating twenty-four hours a day, the shuttle boat service transports boat owners to and from their craft, tied at the buoy area. There is not a scheduled service, but operates when the demand occurs. This requires the primary use of a runabout and driver. The charge for the service is included in the buoy rental fee for the season. As long as the buoy field exists and is in use, the shuttle service must operate on a 24 -hour basis.

\section{Colorado River Float Trips}

The beauty and history of the Southwest on a River Raft Experience along the Colorado River is an excellent experience. Nearly a thousand year ago, Ancestral Puebloans lived in the same Canyon that visitors can river raft through. Guests can imagine canyon walls that rise a thousand feet above them. They can relax while their river guide points out historical landmarks and interesting geologic facts. As they drift along the Canyon River, they may spot beautiful birds such as herons, golden eagles, condors, or even peregrine falcons.

They have the option of choosing a full day or half day trips. They begin below Glen Canyon Dam and cover 15 miles of soothing water. If they choose the full day rafting experience they will be treated with a delicious picnic on the banks of the river. 


\section{Boat and Motor Rental}

Available equipment is up to date and well maintained and consists of:

- 19 houseboats---rental Monday to Friday $\$ 1,200$; Friday to Monday $\$ 1,200$

- $\quad 15$ pontoon boats---hourly rental $\$ 80$ for $3 \mathrm{hrs} ; \$ 140$ for $6 \mathrm{hrs}$.

- 9 runabouts for skiing---\$60-80 per hour

- 15 fishing boats--- $\$ 48$ for 6 hours; $\$ 72$ for 12 hours

The maximum hourly rental is 10 hours per day during the week and 12 hours per day on Saturday and Sunday. Gas is not included in the rental rate.

During the height of the season, it is common to have all nineteen houseboats out all week. The season height starts Memorial Day weekend and ends Labor Day weekend. About 30\% to 40\% of pontoons, runabouts, and fishing boats are rented during the week. The person operating the boat and motor rental for the Marina makes a onethird commission on all boat rental equipment.

\section{Powerboat Rentals}

Rental services are provided. Instructions on how to operate vehicles are provided; all customers need is a driver's license. Here is what's available:

\author{
Powerboats \\ 14' Fishing/Utility Boats \\ 17' Tracker Bass Boat \\ 18' Run About \\ 19' Powerboats \\ 21' Deck Boats \\ 22' Deck Boats
}

\author{
Water Toys \\ Adult and Children Ski Packages \\ Wakeboards \\ Kneeboards \\ Tubes
}

\author{
Boat Type \\ 36' Standard Class \\ 44' Standard Class \\ 50' Standard Class \\ 46' Captain Class \\ 52' Captain Class \\ 54' Sport Class \\ 56' Commodore \\ 59' Admiral Class
}

\section{Storage}

It is better for the boat to remain in the water. Water is better because it gives an even support to the hull. Possible damage from hoists used to lift boats and move them to dry storage is avoided by leaving the craft in the water. An educational program is required for boat owners to understand these factors in order to develop common knowledge. Employees are prohibited from driving the customers' boats by the Marina's rules. The prime reason is the cost of the insurance to cover the employee and the effort of maintaining a duplicate set of keys for each boat. This means that all boats are subject to be towed with possible damage to the boats.

The following are some of the Lake Powel's Promotions:

\section{BEAUTIFUL CRUISE ADVENTURES}

\section{Canyon Cruise Adventures}

Imagine seeing great sciences with steep and red sandstone walls. Cruise through Navajo Canyon and see the dark desert with beautiful views of the towering rock walls, with front row views of Tower Butte and Navajo Arch. You will be able to view the lost canyon of Eden. Or view Moki Canyon, a long and twisting gorge with large water 
caves. And don't forget the Forgotten Canyon, which contains lichen covered walls. Choose out of any of these beautiful Canyons and you can't go wrong.

Trips differ from locations of departure. Antelope Canyon and Canyon Cruised depart from WhaeapWahweap Marina. Canyon Explorer Cruise Adventures depart from Bullfrog and Halls Crossing Marinas. Advance reservations recommended. 10 passenger minimum required. Off season departure time are subject to cancellation or consolidation.

\section{Sunset Dinner}

Indulge in our delicious prime rib or vegetarian Lasagnas dinners as we paddle a wheeler through Canyon King and witness the lake's transformation from afternoon to evening. Colors in the canyon with soften from deep red and burnt orange to lavender, ginger, and silver.

Departs from Wahweap marina. Advance reservations recommended. 10 passenger minimum required. Off season departure time are subject to cancellation or consolidation.

\section{Rainbow Bridge Cruise Adventures}

Take a trip to Rainbow Bridge national Monument. This monument is the world's largest natural stone bridge. Made purely by Mother Nature's winds and water, this 270 feet wide and 290 feed high bridge is quite exquisite and is most likely the most photographed geological wonder in the American West. This rainbow bridge is so stunning it was featured in an article in National Geographic, along with visits by Theodore Roosevelt and western writer Zane Grey.

All day and half day are available. Cruises depart daily form Wahweap Marina and on select days from Bullfrog and Halls Crossing Marinas. Advance Reservation recommended. 10 passenger minimum required. Off season times are subject to cancellation or consolidation.

\section{Wahweap Paddle Wheeler}

Have some time to kill? Take a one hour cruise around Wahweap Bay on the canyon King. The canyon king is an 1800's style paddle wheeler boat. Take this cruise if you want to enjoy all of Lake Powell's unique rock formations surrounding Wahweap Bay.

Advance reservations recommended. 10 passenger minimum required. Off season departure times are subject to cancellation or consolidation.

\section{COMMAND YOUR OWN SHIP}

\section{Powerboat Rentals}

Rent your own boat and plan the trip of your life. You can go far and fast with our powerboats. With these great rentals you can go fishing or weave through canyons and coves with beautiful sceneries. Do not worry if you have never driven a boat, Instructions are provided, all you need is a driver's license. Here is what's available:

\section{Powerboats}

14' Fishing/Utility Boats

17' Tracker Bass Boat

18' Run About

19' Powerboats

21' Deck Boats 
22' Deck Boats

Water Toys

Adult and Children Ski Packages

Wakeboards

Kneeboards

Tubes

\section{Personal Watercraft}

Feel like an adrenaline rush? Rent one of our many watercrafts. Enjoy the freedom of cutting through waves and going at high speeds in an open area. We provide personal flotation devices and training lessons for your safety. We also have wetsuits available for rent.

\section{Kayaks}

We have kayaks available for rent. With these kayaks, you can either power paddle or sit and relax and paddle when you feel like moving. This is a great and entertaining way to work out. Our kayaks are easy to maneuver and take little time to learn.

\section{Houseboat Rentals}

Our greatest feature at Lake Powell is your houseboat rentals. With our boats you could cruise through the calm waters and hideaway in one of the private alcoves. Or anchor up on our beautiful beaches and stretch your feet, start a barbeque, and watch the sunset.

We have different sized boats to accommodate your houseboat needs. Choose from a 36 foot Standard Class with all the necessities you need or pick our 59 foot Admiral lass with four staterooms, two bathrooms, a fully equipped kitchen, central heating, air conditioning, wet bar, VCR, CD sound system and other great features. This houseboat can home 6 to 12 adults comfortably. Our choices include:

Boat Type

36' Standard Class

44' Standard Class

50' Standard Class

46' Captain Class

52' Captain Class

54' Sport Class

56' Commodore

59' Admiral Class

3 Days to full week rentals are available. Rate varies depending on season and package availability, Not all houseboat models are available at every marina. Lake Powell has serviced many happy customers. Here are some comments by pass customers to show you how much our costumers enjoyed their stay here at Lake Powell:

- "Lake Powell is the most spectacular place I've ever been to...It's truly a place you have to see to believe." - Monica Anderson, host of One more Cast as seen on TNN outdoors.

- $\quad$ Dave Hayes and Anne Johnson of the San Diego Union Tribune stayed at Lake Powell and recommend to our future customer that they should barbeque shrimp kebabs on the gas grill of a houseboat and relax on the upper deck of the boat to watch the stars in the sky. 
- $\quad$ "Gradually we wound our way deeper in the canyon until we could touch both walls. A thousand feet overhead in that narrow ark, the moon shines at midday...In our dark retreat the wind is holding its breath, as are we." - Paul Harvey, radio broadcast.

PROFIT LOSS STATEMENT

(Fiscal year ending December 31, 2005)

\begin{tabular}{|c|c|}
\hline Revenue & \\
\hline Restaurants & $\$ 3,097,408$ \\
\hline Sale of used boats & 718,580 \\
\hline Sale of rental boats & 68,204 \\
\hline Total Sales: & $\$ 3,884,192$ \\
\hline \multicolumn{2}{|l|}{ Other income } \\
\hline Service and repair & $\$ 514,748$ \\
\hline Gasoline and oil & 325,316 \\
\hline River Raft & 364,856 \\
\hline Slip rental & 699,232 \\
\hline Gift shop & 128,708 \\
\hline Boat rental & 399,580 \\
\hline Total & $\$ 2, \overline{432,440}$ \\
\hline Total Income: & $\$ 6,316,632$ \\
\hline \multicolumn{2}{|l|}{ Expenses } \\
\hline \multicolumn{2}{|l|}{ Fixed Costs: } \\
\hline Cost of boats & $\$ 3,192,492$ \\
\hline Cost of repair equipment & 226,792 \\
\hline Restaurant material costs & 257,620 \\
\hline Cost of gasoline & 207.528 \\
\hline Boat rental costs & $\underline{35.804}$ \\
\hline Total Fixed Costs: & $\$ 3,920,236$ \\
\hline \multicolumn{2}{|l|}{ Operating Expenses } \\
\hline Wages and salaries & $\$ 912,616$ \\
\hline Taxes & 94,900 \\
\hline Building rent & 232,464 \\
\hline Equipment rent & 35,900 \\
\hline Utilities & 74,864 \\
\hline Insurance & 100,000 \\
\hline Interest on loans & 837,240 \\
\hline Advertising & 120,420 \\
\hline Legal expense & 77,800 \\
\hline Bad debt expense & 34,924 \\
\hline Miscellaneous & 159,976 \\
\hline Total Operating Expenses: & $\$ 2, \overline{681,104}$ \\
\hline Total costs & $\$ 6,601,340$ \\
\hline Operating loss & $(\$ 284,708)$ \\
\hline Depreciation & $\$ 489,540$ \\
\hline Total Loss: & $(\$ 774,248)$ \\
\hline
\end{tabular}

This represents the total operating loss of the Lake Powell in the fiscal year ending December 31, 2005. Lake Powell sold a subsidiary in 2005 (boat sales firm in Los Angeles) which they wrote off a loss of \$1,102,320. 
BALANCE SHEET

(December31, 2005)

\begin{tabular}{|c|c|c|c|c|}
\hline \multicolumn{2}{|c|}{ Assets } & \multicolumn{3}{|c|}{ Liabilities } \\
\hline $\begin{array}{l}\text { Current assets: } \\
\text { Cash } \\
\text { Accounts receivable } \\
\text { New boats } \\
\text { Used boats } \\
\text { Parts } \\
\text { Slip store } \\
\text { Gas/oil } \\
\text { Total current assets }\end{array}$ & & $\begin{array}{r}\$ 127,432 \\
282,528 \\
796,116 \\
242,988 \\
213,180 \\
9,884 \\
10504 \\
\$ 1,683,712\end{array}$ & $\begin{array}{l}\text { rent liabilities: } \\
\text { Accounts payable } \\
\text { Inter company payables } \\
\text { Accrued salary expense } \\
\text { Accrued interest expense } \\
\text { Accrued tax expense } \\
\text { Accrued lease expense } \\
\text { Prepaid dock rental } \\
\text { Boat deposits } \\
\text { Current bank notes } \\
\text { Mortgage (current) } \\
\text { Note payable to the Lodge } \\
\text { Notes to stockholders } \\
\text { Dealer reserve liability } \\
\text { Total current liabilities }\end{array}$ & $\begin{array}{r}\$ 357,732 \\
1,868,364 \\
35620 \\
81,532 \\
174,876 \\
144,760 \\
713,864 \\
17,152 \\
710,400 \\
3,931,600 \\
902,200 \\
2,060,600 \\
55,700 \\
\$ 11,340,900\end{array}$ \\
\hline $\begin{array}{l}\text { Fixed assets: } \\
\text { Buoys and docks } \\
\text { Permanent bldgs. } \\
\text { Office furniture } \\
\text { Houseboats } \\
\text { Work boats } \\
\text { Equipment }\end{array}$ & $\begin{array}{l}\$ 3,937,060 \\
807,900 \\
13,040 \\
556,540 \\
163,220 \\
289,680 \\
5,767,440\end{array}$ & $\begin{array}{r}\text { Less depr. } \\
\$ 1,261,800 \\
71,528 \\
2,816 \\
62,524 \\
31,948 \\
154,968 \\
\$ 1,585,584\end{array}$ & & \\
\hline & & & Long term note on houseboats & 470,700 \\
\hline Net fixed assets & & $\$ 4,181,856$ & & \\
\hline $\begin{array}{l}\text { Other assets: } \\
\text { Prepaid expense } \\
\text { Deferred interest exp. }\end{array}$ & & $\begin{array}{r}\$ 11,760 \\
101,284 \\
\$ 113,044\end{array}$ & $\begin{array}{l}\text { Common stock-100,000 } \\
\text { shares at par value } \$ 1 / \text { share }\end{array}$ & 100,000 \\
\hline Total assets & & $\$ 5,978,612$ & $\begin{array}{l}\text { Retained earnings } \\
\text { Loss during year ending } \\
\text { December } 31,2005 \\
\text { Total }\end{array}$ & $\begin{array}{r}(4,056,420) \\
(1,876,568) \\
\$ 5,978,612\end{array}$ \\
\hline
\end{tabular}

